慶應義塾大学学術情報リポジトリ

Keio Associated Repository of Academic resouces

\begin{tabular}{|c|l|}
\hline Title & $\begin{array}{l}\text { Determination of hydroperoxides with the use of immobilized glutathione peroxidase in a flow } \\
\text { system }\end{array}$ \\
\hline Sub Title & \\
\hline Author & $\begin{array}{l}\text { 森, 久和(Mori, Hisakazu) } \\
\text { 小暮, 真美絵(Kogure, Mamie) } \\
\text { 隈部(山品), 恭子(Kumabe(Yamashina), Kyoko) }\end{array}$ \\
\hline Publisher & 共立薬科大学 \\
\hline Publication year & 1992 \\
\hline Jtitle & $\begin{array}{l}\text { 共立薬科大学研究年報 (The annual report of the Kyoritsu College of } \\
\text { Pharmacy). No.37 (1992.),p.62-62 }\end{array}$ \\
\hline JaLC DOI & \\
\hline Abstract & \\
\hline Notes & 抄録 \\
\hline Genre & Technical Report \\
\hline URL & https://koara.lib.keio.ac.jp/xoonips/modules/xoonips/detail.php?koara_id=AN00062898-0000003 \\
7-0062
\end{tabular}

慶應義塾大学学術情報リポジトリ(KOARA)に掲載されているコンテンツの著作権は、それぞれの著作者、学会または出版社/発行者に帰属し、その権利は著作権法によって 保護されています。引用にあたっては、著作権法を遵守してご利用ください。

The copyrights of content available on the KeiO Associated Repository of Academic resources (KOARA) belong to the respective authors, academic societies, or publishers/issuers, and these rights are protected by the Japanese Copyright Act. When quoting the content, please follow the Japanese copyright act. 
No. 37 (1992)

\title{
Determination of Hydroperoxides with the Use of Immobilized Glutathione Peroxidase in a Flow System*
}

\author{
Hisakazu Mori, Mamie Kogure and Kyoko Kumabe (nee Yamashina) \\ 森 久和, 小暮真美絵, 隅部(旧姓山品）恭子
}

\begin{abstract}
Various hydroperoxides were determined in a flow system with the use of glutathione peroxidase immobilized on $\mathrm{N}$-(2-aminoethyl)-3-aminopropyl glass. In this system, the glutathione diminished by the reaction with hydroperoxide was monitored through its reaction with 5,5'-dithio-bis-(2-nitrobenzoic acid). The optimum $\mathrm{pH}$ for this immobilized enzyme was found to be 7.8. The rates of three carrier solutions were examined to obtain a favorable peak. The calibration curves for hydrogen peroxide, tert-butyl hydroperoxide, cumene hydroperoxide, linoleate hydroperoxide and linolenate hydroperoxide showed high linearity over the sample concentration range from not more than 10 to $100 \mu \mathrm{M}$. The detection limits for the above hydroperoxides were in the range from 0.2 to $0.5 \mathrm{nmol}$. The determination of hydroperoxides could be performed in $4 \mathrm{~min}$.
\end{abstract}

* 本報告は Anal. Lett., 25 (9)，1643-1656（1992）に発表. 